\title{
Comparative evaluation of the quality changes in squid (Ommastrephes bartrami) during flake and slurry ice storage
}

\author{
Pengxiang Yuan ${ }^{1,38}$, Shanggui Deng ${ }^{1 * \&}$, Shaimaa Hatab ${ }^{1,2}$, Ning Yuan ${ }^{1}$, Jiancong Huo ${ }^{1}$ \\ ${ }^{1}$ College of Food and Pharmacy, Zhejiang Ocean University, Zhoushan, Zhejiang, China, ${ }^{2}$ Department of Food Science, College of \\ Environmental Agricultural Sciences, Arish University, Al-Arish, North Sinai, Egypt, ${ }^{3}$ Department of Food Science and Technology, Graduate \\ School of Fisheries and Environmental Sciences, Nagasaki University, Nagasaki, Japan \\ \&These authors contributed equally to this work
}

\section{A B S TR A C T}

Raw squid suffers a rapid quality loss which occurs after catch immediately and during ice storage. This research is a comparative study between the effect of Slurry ice (SI), a binary mixture consists of $40 \%$ ice and $60 \%$ filtered seawater (salinity: $3.3 \%$ ), and Flake ice (FI) on the quality parameters of squid (Ommastrephes bartrami) during storage period. Different analysis such as salinity, moisture, TVB-N, myofibrillar protein, microbiological, total sulphur (SH), and ATPase activity, which are related to the quality changes, were analyzed during the storage period ( 15 days). The rapid decline in the initial temperature with $\mathrm{SI}\left(0.83^{\circ} \mathrm{C} \mathrm{min}{ }^{-1}\right)$ resulting in a significant reduction of total aerobic bacteria, extend the shelf life, and better control of water content. It was found that the squid stored on SI has significantly higher content of myofibrillar protein $\left(30 \mathrm{mg} \mathrm{ml}^{-1}\right)$ compared with the samples stored on $\mathrm{Fl}\left(24.26 \mathrm{mg} \mathrm{ml}^{-1}\right)$ at the end of storage time. Additionally, the storage of squid on SI retard the formation of TVB-N, where the samples content of TNB-N after 15 days of storage were $\left(13.26 \mathrm{mg} \mathrm{N}(100 \mathrm{~g})^{-1}\right)$, while in the FI samples TVB-N content reached to $\left(30 \mathrm{mg} \mathrm{N}(100 \mathrm{~g})^{-1}\right)$. Similarly, the Ca2 ${ }^{+}$-ATPase activity, and total sulfhydryl $(\mathrm{SH})$ content in squids treated with $\mathrm{SI}$ were significantly $(P<0.05)$ higher than the $\mathrm{FI}$ samples. Our results indicate that, the application of SI to squid is advisable to achieve better quality maintenance during storage and distribution.

Keywords: Chemical quality; Microbiological quality; Shelf life; Slurry ice, Squid.

\section{INTRODUCTION}

Cephalopods constitute an important part of the marine resource and most suitable for human consumption (Jeyasekaran et al., 2010). Squid, belonging to the class of Cephalopod, is one of the most common seafood dishes at many parts of the world. It is considered low in Saturated Fat and Sodium and a good source of Niacin, Zinc, Protein, Riboflavin, Vitamin $B_{12}$, Phosphorus, Copper, Manganese and Selenium (Vleeming et al., 1999). However, the raw squid suffers a rapid quality loss by producing various offodor components, that mainly caused by trimethylamineN-oxide (TMAO) reduction and microbial contamination which occur immediately after the catch and during storage in ice (Sungsri-in et al., 2011; Ramirez-Suarez et al., 2008; Gou et al., 2010). Therefore, the refrigeration immediately after catch is required, to slow down the susceptibility of squid to spoilage and quality loss. Traditionally, flake ice, refrigerated sea water, modified atmospheres, brine solutions, the incorporation of chemical preservative agents and slurry ice have been used for the preservation of fresh aquatic food products (Múgica et al., 2008).

Slurry ice, a binary mixture of small spherical ice crystals surrounded by seawater at subzero temperature, has been reported to be a promising technique for the preservation of aquatic food products (Rodríguez et al., 2006; Huidobro et al., 2002). Slurry ice has many features including (I) fast cooling rate resulting from the large heat transfer surface area created by its numerous particles, (II) the sub-zero storage of the seafood material (III) the latent heat of fusion of its ice crystals led to a high energy storage density (IV) spherical particles of the slurry ice play an main role in reducing the physical damage of seafood surface,

\footnotetext{
${ }^{*}$ Corresponding author:

Prof. Dr. Shanggui Deng, College of Food and Pharmacy, Zhejiang Ocean University, Zhoushan, Zhejiang 316000, China.

Tel.: +86-580-2552539. Fax.: + 86-580-2552539. E-mail: dengshanggui@163.com
}

Received: 23 August 2016;

Revised: 13 March 2017;

Accepted: 19 March 2017;

Published Online: 29 March 2017 
and thus reduces dehydration and oxidation events $(\mathrm{V})$ the complete coverage of the seafood surface (Piñeiro et al., 2004; Aubourg et al., 2007; Kauffeld et al., 2010).

Several studies suggest that slurry ice is a promising technology to improve the quality for a wide range of fish species (Piñeiro et al., 2004). For example, European Hake (Merluccius merluccius) (Losada et al., 2004), horse mackerel (Trachurus trachurus) (Losada et al., 2005), salmon (Oncorbynchus kisutch) (Rodríguez et al., 2008), seabass (Dicentrarchus labrax) (Cakli et al., 2006) and pink shrimp (Parapenaeus longirostris) (Huidobro et al., 2002).

Although these advantages and applications of slurry ice are well known, few studies are available on the ability of slurry ice to extend the shelf-life of squid and enhance the quality parameters (Ommastrephes bartrami). Therefore, the objective of this study was to compare the effects of slurry ice and flake ice treatment on the microbiological, and chemical parameters of Squid (Ommastrephes bartrami).

\section{MATERIALS AND METHODS}

\section{Preparation of flake ice (FI) and slurry ice (SI)}

An ice system (RF-1000-SP, JiangSu, China) was used to prepare the slurry ice (SI). The ice slurry mixture was consisted of 70\% ice and 30\% filtered seawater (salinity $3.0 \%$ ). The temperature of the SI mixture ranged from -2.0 ${ }^{\circ} \mathrm{C}$ to $-2.5^{\circ} \mathrm{C}$. Flake ice $(\mathrm{FI})$ was prepared using freshwater with a compact device (SM-F140AY65, HITACHI, Japan); the temperature of the FI ranged from 0 to $0.8^{\circ} \mathrm{C}$.

\section{Fish material, processing, and sampling}

Fresh squid (Ommastephes bartrami) of approximately 10 to $15 \mathrm{~cm}$ body length and approximately $70.0 \mathrm{~g}$ body weight were provided by Zhejiang XingYe Company (Zhoushan, China). Squids were transferred to the laboratory within 30 min into aseptic bags and stored in zero degrees using portable refrigeration box. Upon arrival in the laboratory they were divided into two groups and placed in SI or FI at a ratio of 13 (fish to ice), before being stored in a refrigerated room at $0^{\circ} \mathrm{C}$ for 15 days. The FI and SI were renewed every day during the storage period. To determine the cooling curves for squid stored in SI and FI the temperature of different parts of squid was measured by multiplex temperature tester (JK-24U, JiangSu, China) every $0.5 \mathrm{~min}$ for $30 \mathrm{~min}$.

For each chilling treatment, three carcasses without skin and cartilage were studied separately throughout the whole experimental period. Every three days, the samples were subjected to chemical and microbial analyses.

\section{Determination of salinity and moisture content}

To determine the salinity level in the squid muscles, about $10.0 \mathrm{~g}$ minced squid were mixed with $100 \mathrm{ml}$ water $\left(70^{\circ} \mathrm{C}\right)$ and boiled for $15 \mathrm{~min}$ with shaking. The samples were homogenized for $1.0 \mathrm{~min}$ (high speed) before cooled to room temperature. Then the salinity content was measured using salinometer (YSI EC300, America) as described by Chinese National Standard GBT 12457-2008.

Moisture content was determined by Automatic moisture meter (HG63, METTLER, Switzerland) according to Chinese National Standard (GB 5009-2010). $5.0 \mathrm{~g}$ minced squid were placed on the specimen disc with zero clearing, the moisture contents were measured directly and recorded, each sample was measured five times.

\section{Determination of total volatile basic nitrogen (TVB-N)} Total Volatile Bases Nitrogen (TVB-N) was measured by automatic kjeldahl apparatus (FOSS-8400, Sweden). The results were expressed as mg N (100g)-1 muscle. Squid samples prepared as described by (Aubourg et al., 1997) with slight modification. briefly, $10 \mathrm{~g}$ of squid sample was homogenized with $90 \mathrm{ml}$ of $0.6 \mathrm{M}$ perchloric acid solution for 1 min using a laboratory homogenizer. The homogenate was centrifuged at $10000 \mathrm{rpm}$ for $10 \mathrm{~min}\left(4^{\circ} \mathrm{C}\right)$ and the supernatant was filtered through Whatman No. 1 filter paper.

\section{Microbiological analyses}

The total bacterial load was determined using pour-plate method. Samples $(25.0 \mathrm{~g})$ were transferred to a sterile blender Jar containing $225 \mathrm{ml}$ of sterile $1 \%$ peptone water (PW) and homogenized for 2 min using a stomacher. Serial dilutions of each homogenate were carried out with $0.1 \%$ PW. Appropriate dilutions $(1 \mathrm{ml})$ were plated onto plate count agar (GB/T 4789.1-2010, China). The plates were incubated at $30^{\circ} \mathrm{C}$ for $48 \mathrm{~h}$ to enumerate the total bacteria count.

\section{Myofibrillar protein analyses}

To isolate myofibrils from muscle, about $10.0 \mathrm{~g}$ minced flesh was homogenized in $100 \mathrm{ml}$ of $20 \mathrm{mM}$ Tris-maleic acid solution (containing $0.05 \mathrm{mM} \mathrm{KCL}, \mathrm{pH} 7.0$ ). The homogenate was centrifuged at $10000 \mathrm{rpm}$ for $10 \mathrm{~min}$ $\left(-4^{\circ} \mathrm{C}\right)$, the supernatant discarded and the sediment, containing most of myofibrillar was resuspended in $100 \mathrm{ml}$ of $20 \mathrm{mM}$ Tris-maleic acid solution (containing $0.6 \mathrm{mM}$ $\mathrm{KCL}, \mathrm{pH} 7.0$ ) and centrifuged again for $5 \mathrm{~min}$ at $9000 \mathrm{rpm}$ $\left(-4{ }^{\circ} \mathrm{C}\right)$. The resulting supernatant that contains total myofibril protein solution, was measured by biuret method (Gornall et al. 1949).

\section{Determination of $\mathrm{Ca}^{2+}$-ATPase activity}

ATPase activities were determined as described by (Ooizumi and Xiong, 2004). To prepare the reaction 
mixture the following chemicals were added: $0.5 \mathrm{M}$ Trismaleic acid-containing buffer ( $\mathrm{pH} 7.0), 0.1 \mathrm{M} \mathrm{CaCl}_{2}$, $\mathrm{H}_{2} \mathrm{O}, 20 \mathrm{mM}$ ATP solution and myofibrillar proteins. The reaction mixture was incubated for $5 \mathrm{~min}$ at $30^{\circ} \mathrm{C}$ in a water bath, and terminated by adding $1.0 \mathrm{ml}$ of chilled $15 \%(\mathrm{w} / \mathrm{v})$ trichloracetic acid (TCA) solution. The blank group was mixed with $1.0 \mathrm{ml} \mathrm{15 \%}$ TCA solution to denature proteins before the reaction. $1.0 \mathrm{ml}$ sulfuric acid molybdate, $0.5 \mathrm{ml}$ metal and $2.5 \mathrm{ml}$ water were added to $1.0 \mathrm{ml}$ reaction mixture followed by incubated for $45 \mathrm{~min}$ at room temperature and then measured at $640 \mathrm{~nm}, 0.5 \mathrm{mM}$ $\mathrm{KH}_{2} \mathrm{PO}_{4}$ was used as a standard. the following formula has been used to calculate $\mathrm{Ca}^{2+}$-ATPase

$\mathrm{Ca}^{2+}$-ATPase $=(\mathrm{A}-\mathrm{B}) /(\mathrm{t} \times \mathrm{C})$

Where (A) refer to $1.0 \mathrm{ml}$ phosphoric acid generated in the reaction solution $(\mu \mathrm{M})$; (B) is phosphoric acid generated in the Blank $(\mu \mathrm{M}) ;(\mathrm{T})$ is the reaction time ( $\mathrm{min})$ and $(\mathrm{C})$ is The content of enzyme in $1.0 \mathrm{ml}$ reaction solution.

\section{Determination of total sulphur (SH)}

The method described by (Zhang et al., 2015) has been used to measure total SH content, briefly, $1.0 \mathrm{ml}$ myofibril protein was added to $9.0 \mathrm{ml} 0.2 \mathrm{M}$ Tris-HCL buffer containing $8.0 \mathrm{M}$ carbamide, $2 \%(\mathrm{w} / \mathrm{v})$ sodium dodecyl sulfate (SDS) and $10 \mathrm{mM}$ EDTA, (pH6.8). Thereafter, $4.0 \mathrm{ml}$ of this mixture was added into $0.4 \mathrm{ml}$ of $0.1 \%$ (w/v) DTNB solution (containing 0.2 M Tris- $\mathrm{HCl}, \mathrm{pH} 8.0$ ) and further subjected to incubation at $40^{\circ} \mathrm{C}$ for $25 \mathrm{~min}$ in a water bath. Then the absorbance of the mixture was measured at $412 \mathrm{~nm}$ using a spectrophotometer (U2800, HITACHI, Japan). A blank was prepared by replacing the sample with $0.6 \mathrm{M} \mathrm{KCl}$. Total SH content was calculated by the following formula

$\mathrm{CO}=(\mathrm{A} \times \mathrm{D}) /(\mathrm{C} \times \mathrm{B})$

Where CO SH molar concentration; A absorbance value on $420 \mathrm{~nm}$; D dilution ratio; $C$ protein concentration $\left(\mathrm{mgml}^{-1}\right)$ and $\mathrm{B}$ molecular absorption coefficient $13600\left(\mathrm{M}^{-1} \mathrm{~cm}^{-1}\right)$;

\section{Statistical analyses}

All experiments were performed in triplicate, and the data were presented as means \pm standard deviation (SD). Statistical analyses were performed with the Excel and SPD7.05. In all cases, $P$-values with $(P<0$ AE05) were considered statistically significant.

\section{RESULTS AND DISCUSSION}

Cooling curves for squid placed in SI or FI are shown in (Fig. 1). The results indicated that the SI cooled the squid quite rapidly than the FI. The FI cooled the squid core temperature to $-0.4 \sim-0.5^{\circ} \mathrm{C}$ in approximately $30 \mathrm{~min}$, while the SI could cool the squid core temperature to $-1.1 \sim-1.3^{\circ} \mathrm{C}$ within the same time. The cooling rates were $0.83^{\circ} \mathrm{C} \mathrm{min}^{-1}$ and $0.50{ }^{\circ} \mathrm{C} \mathrm{m^{-1 }}$ for SI and FI, respectively. This rapid cooling rate is desirable as degradation by bacteria and enzymes is quickly suppressed at low-temperature and that leading to extending shelf-life and kept the squid fresh (Leelapongwattana et al. 2008, Wang et al. 2003, Gou et al. 2010). In general, slurry ice was produced by mixing crushed ice with seawater (salinity 3.0\%), resulting in a freezing point below $0.0^{\circ} \mathrm{C}(\mathrm{Gao} 2010)$.

\section{Moisture content and salinity analyses}

Significant differences $(P<0.05)$ were observed in moisture content between the squid stored in SI and FI (Fig. 2). Fresh squid samples had water contents of $83.72 \%$, which increased gradually to $86.64 \%$ at the end of storage period in SI. While in the sample stored in FI the water content decreased to $78.35 \%$ after 15 days. The losing in water content refers to disruption of the muscle structure and denaturation of myofibrillar proteins and sarcoplasmic, resulting in to a decreasing water holding capacity of the protein fraction (Castrillón et al., 1996; Rodríguez et al., 2008).

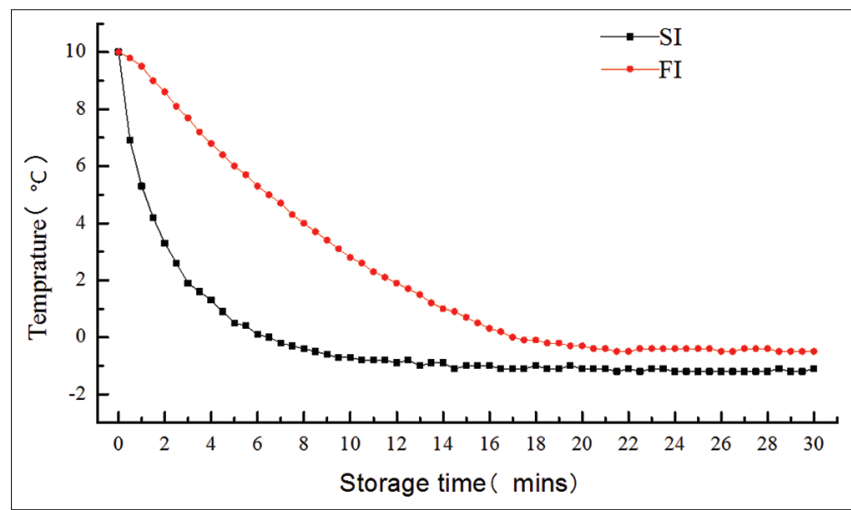

Fig 1. Cooling curves for squids during $30 \mathrm{~min}$ of pre-cooling in slurry ice (SI) and flake ice $(\mathrm{FI})$. The temperature of refrigerator room set to $4^{\circ} \mathrm{C}$.

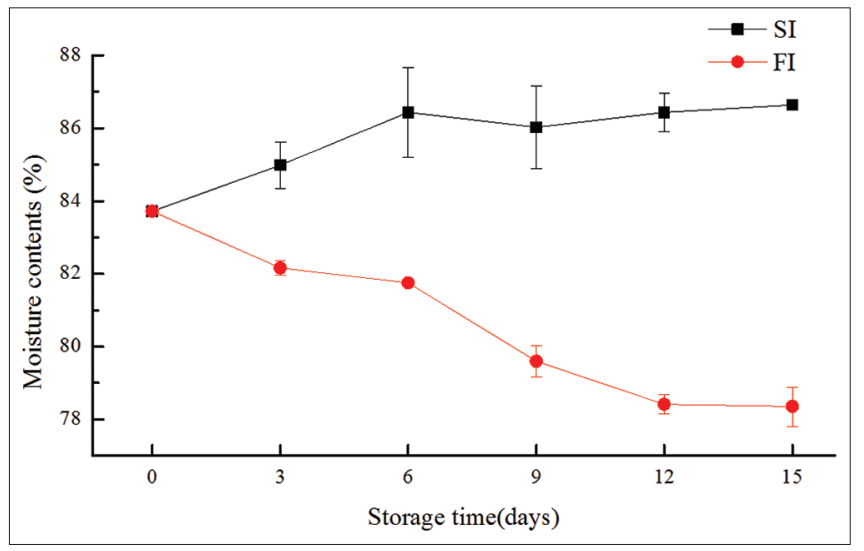

Fig 2. Water content (\%) of squid during storage in slurry ice (SI) and flake ice $(\mathrm{FI})$. Average of three replicates and standard deviation are presented. 
The salinity content of the squid stored in SI increased from 0.52 to $2.81 \%$ at the end of the storage period (15 days), while the squid stored in FI changed slightly and the senility content was $0.58 \%$ after 15 days (Fig. 3 ). The absorption of $\mathrm{NaCl}$ into the fish during the storage period in slurry ice was found to be slow (Losada et al., 2005; Rodríguez et al., 2008; Losada et al., 2004). The increasing in salinity can enhance the water holding capacity and inhibit the growth of microbial during the storage period of marine species (Lei Y. et al., 2007). It is worth mentioning that the increasing in salinity of squid stored in SI would not affect the quality properties.

\section{Total volatile basic nitrogen (TVB-N) analyses}

The TVB-N content normally produced as a result of microbiological activity during the chilling storage (Lei Y. et al., 2007; Rodríguez et al., 2008), and the TVB-N contents should not be more than $30 \mathrm{mg} \mathrm{N}(100 \mathrm{~g})^{-1}$ for fresh and frozen aquatic products according to Chinese National Hygienic Standard (GB2733-2005).

Fresh squid samples had a TVB-N content of $12.46 \mathrm{mg}$ $\mathrm{N}(100 \mathrm{~g})^{-1}$, and the TVB-N formation in the squid stored in FI was significantly $(P<0.05)$ higher than in SI (Fig. 4). At the end of storage period, the TVB-N concentration was $13.26 \mathrm{mg} \mathrm{N}(100 \mathrm{~g})^{-1}$ in squid muscles from SI batches, while these values rose above $30 \mathrm{mg} \mathrm{N}(100 \mathrm{~g})^{-1}$ after 9 days of storage in FI. Similar results have been obtained with different marine species such as horse mackerel (Rodríguez et al., 2005), turbot (Campos et al., 2006), and ray specimens (Múgica et al., 2008).

\section{Microbiological analyses}

The comparative evaluation of microbial growth in squid during storage in SI or FI is displayed in Fig. 5, the use of SI significantly $(P<0.05)$ reduce the microbial growth when compared to FI. Where, the initial microbial load of $6 \log \mathrm{CFUg}^{-1}$ was maintained after 12 days of storage in FI, and increasing to $6.61 \log \mathrm{CFUg}^{-1}$ at the end of storage period. While the counts of total viable bacteria in squid muscle stored in SI were $4.74 \log \mathrm{CFUg}^{-1}$ after 15 days of storage period. Previous reports have also described significantly lower bacterial growth in lobster stored in SI, as compared to conventional flake ice (Aubourg et al., 2007). Additionally, several studies showed a significant slowing down of microbial activity in other marine species, such as shrimp (Huidobro et al., 2002), sardine (Campos et al., 2006), horse mackerel (Rodríguez et al., 2005), and hake (Rodrìguez et al., 2004) during stored in SI. The reasons for the limited bacterial growth, that found in squid stored in slurry ice, definitely are subzero temperature achieved with storage on SI, and the surface wash caused by the liquid phase of the slurry ice. (Rodríguez et al., 2005).

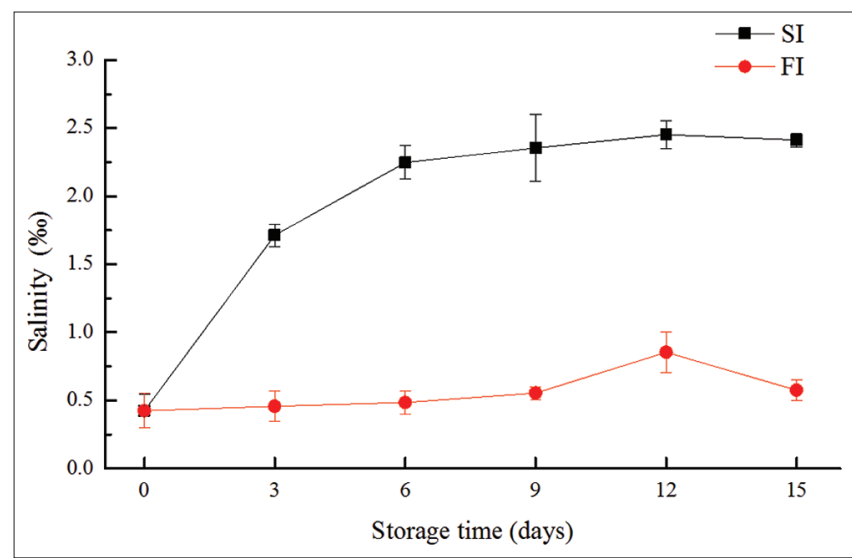

Fig 3. Salinity content (\%) of squid during storage in slurry ice (SI) and flake ice $(\mathrm{FI})$. Average of three replicates and standard deviation are presented.

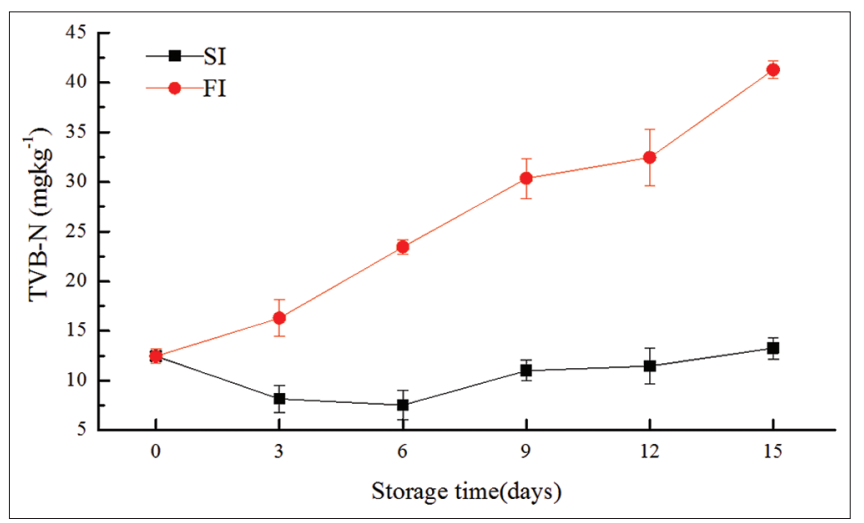

Fig 4. Total volatile base nitrogen (TVB-N) contents of the squids during storage in slurry ice $(\mathrm{SI})$ or flake ice $(\mathrm{FI})$. Bars represent the standard deviation.

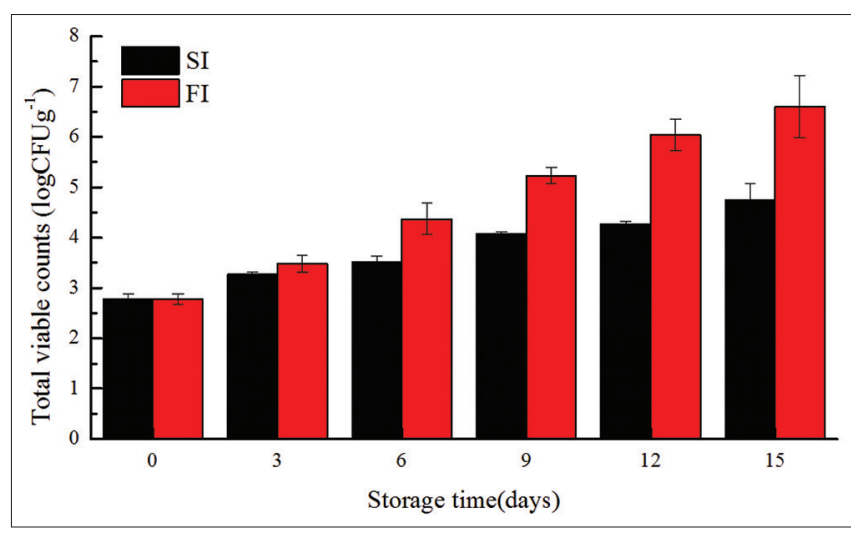

Fig 5. Total microbial count of squids during storage in slurry ice (SI) or flake ice $(\mathrm{FI})$. Bars represent the standard deviation.

\section{Myofibrillar protein analyses}

Myofibrillar proteins constitute as the major protein in the marine organisms muscle (about $70-80 \%$ ) and play an essential role in many functions (Benjakul et al., 2011). the decreases of water holding capacity, juiciness and changes in the textural attributes, resulted from the denaturation and 
aggregation of myofibrillar proteins. This lead to a hard, dry and fibrous marine product with low eating quality. (Careche et al., 1998; Careche et al., 1999; Lu et al., 2012).

As shown in Fig. 6, the content of extractable myofibrillar proteins in squid muscle decreased significantly $(P<0.05)$ over the storage period. Thus, the myofibrillar content of squid samples stored in FI decreased from $62.64 \mathrm{mg} \mathrm{ml}^{-1}$ (Day 0) to $24.26 \mathrm{mg} \mathrm{ml}^{-1}$ on the $15^{\text {th }}$ day. However, the SI treated samples were in good condition and the extractable myofibrillar content remained at $30 \mathrm{mg} \mathrm{ml}^{-1}$ at the end of storage time (15 days). The main changes in myofibrillar are reported to occur in myosin light-chain but actin and actinin also degrade during storage period (Careche et al., 1998; Kjaersgard et al., 2006; Schubring, 2005). Numerous studies attributed the degradation of myofibrillar to proteases such as cathepsins, as well as calcium-dependent proteases (Okitani et al., 1980; Zhang et al., 2015). In several marine species, cathepsins $\mathrm{B}, \mathrm{D}$, and $\mathrm{L}$ were considered as the enzymes playing the most important role in postmortem muscle softening (Ladrat et al., 2003). Our results could be explained based on a faster cooling rate of slurry ice treatment that leads to a lower temperature, thus, formation of large number of small ice crystals in muscle nuclei, preventing the irreversible destruction of the myofibrils by large ice crystals. More importantly, the concentrations of sodium chloride in the SI is similar to its concentration in marine water, that cause stabilization of the myofibrillar protein fraction implying larger yields during storage, and thus enhancing the quality parameters (Kauffeld et al., 2010).

\section{$\mathrm{Ca} 2+-$ ATPase analyses}

As a general trend, $\mathrm{Ca}^{2+}$-ATPase activity in the squid muscle changed reversely with storage time $(P<0.05)$ (Fig. 7). The initial $\mathrm{Ca}^{2+}$-ATPase activity of fresh squid muscle ( 0 day) was $0.48 \mu$ molPi mg ${ }^{-1}$ min-1, then the $\mathrm{Ca}^{2+}$-ATPase activity significantly decreased to $0.1 \mu \mathrm{molPi} \mathrm{mg}^{-1}$ min-1 for the FI $(P<0.05)$ after 15 days of storage. While the $\mathrm{Ca}^{2+}$-ATPase activity remained at $0.2 \mu$ molPi mg ${ }^{-1} \mathrm{~min}^{-1}$, in the samples stored on SI at the same time (Fig. 6). The decreases in $\mathrm{Ca}^{2+}$-ATPase activity was also observed with oxeye scad (Selar boops), shrimp scad (Alepes djedaba) and queen fish (Chorinemus bysan) during ice storage (Chantira et al., 2013). The aggregation as well as the changes of myosin globular head led to reduction in the ATPase activity (Reza et al., 2009). In addition, the rearrangement of protein via protein-protein interactions contributed mainly in the loss of ATPase activity (Benjakul and Bauer, 2000; Reza et al., 2009; Hossain et al., 2005). However, the SI samples maintained a comparatively higher activity of $\mathrm{Ca}^{2+}$-ATPase, that caused by an increased stabilization of myofibrillar protein fraction, indicating larger yields during the storage and processing.

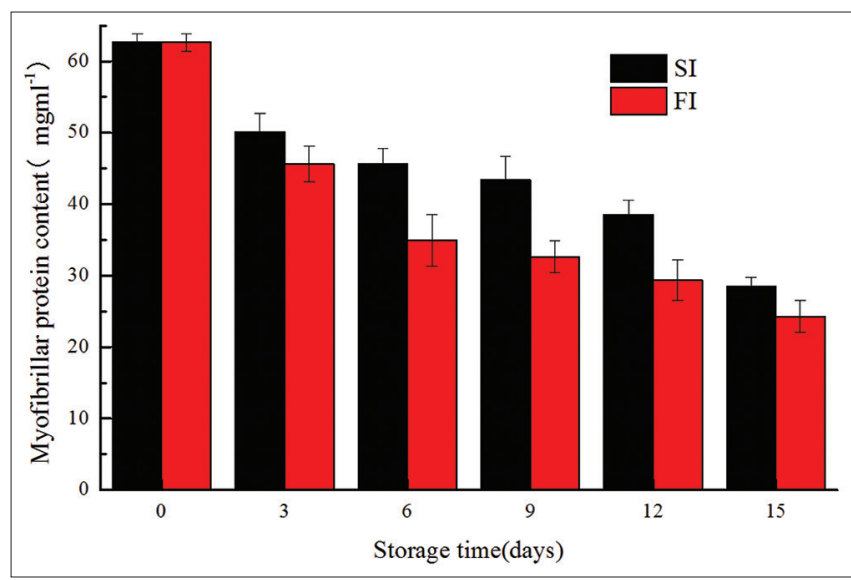

Fig 6. Myofibrillar protein content in squids during storage in Flake ice $(\mathrm{FI})$, and slurry ice $(\mathrm{SI})$. Bars represent the standard deviation.

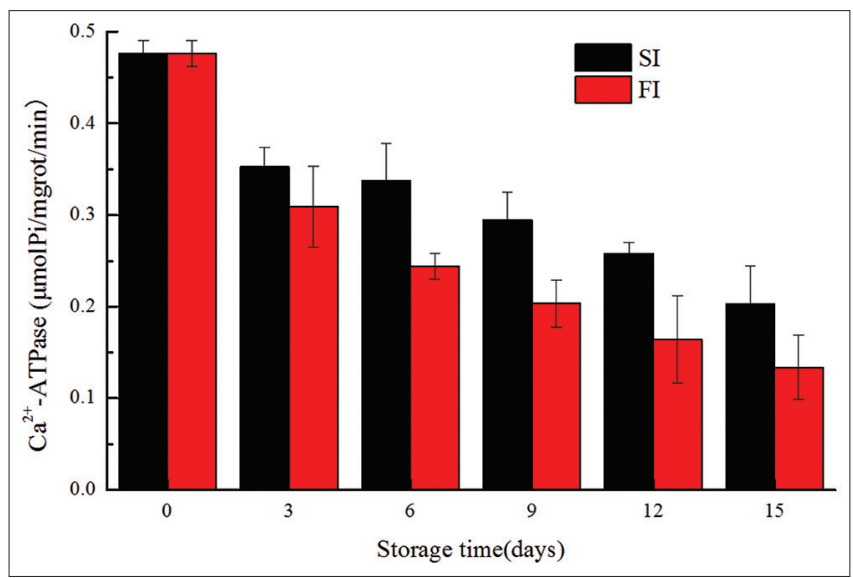

Fig 7. $\mathrm{Ca}^{2+}-$ ATPase activity of squids during storage in flake ice (FI), and slurry ice (SI). Error bars represent standard deviations.

\section{Total sulphur (SH) analyses}

Total sulfhydryl (SH) content of squid at day (0) was about $4.53 \times 10^{-5} \mathrm{~mol} \mathrm{~g}^{-1}$. A sharp decline in SH content was found in the squid samples stored in FI group $\left(1.53 \times 10^{-5} \mathrm{molg}^{-1}\right)$ over the storage period (Fig. 7). While, SI samples remained at $2.24 \times 10^{-5} \mathrm{molg}^{-1}$ after 15 days (Fig. 8). It was also found that the content of $\mathrm{SH}$ in the tuna samples stored on slurry ice were significantly higher $(P<0.05)$ than those sample stored on flake-iced (Zhang et al., 2015). In the other study, (Riebroy et al., 2007) reported that the formation of disulphide bonds through oxidation of SH groups or disulphide interchanges, resulted in decrease in total content of $\mathrm{SH}$ in muscle. In this study, the SI treatment allowed squid sample to reach subzero temperatures rapidly that resulted in decrease the enzymatic breakdown reactions and the oxidation, and thus reducing the polymerization denaturation degree of squid protein(Zhang et al., 2015). 


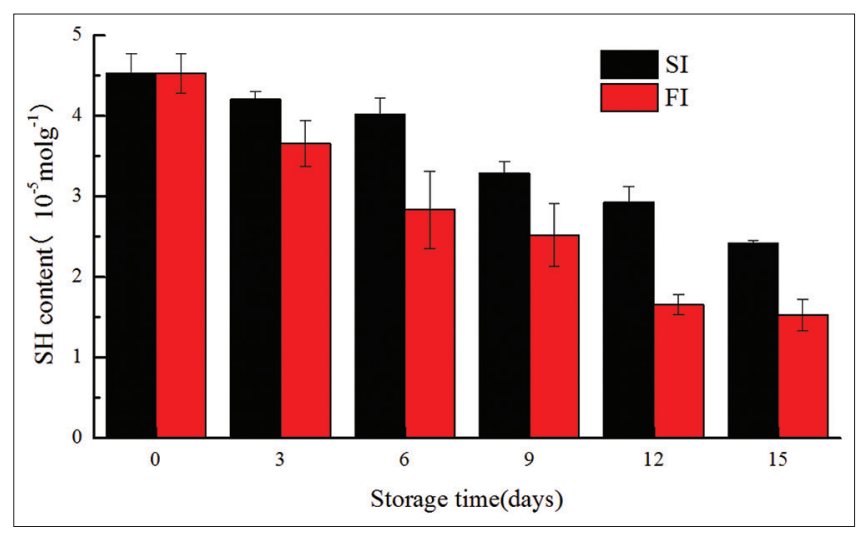

Fig 8. Total SH content of squids during storage in flake ice (FI), and slurry ice (SI). Error bars represent standard deviations.

\section{SUMMARY AND CONCLUSION}

The effect of slurry ice on the quality of squids during storage was investigated and compared to flake ice. The storage of squid samples on Slurry ice led to slow down the degradation of Myofibrillar proteins, decrease the of $\mathrm{Ca}$ $2+$-ATPase activity, total SH content, and total microbial count, and thus stability of tissue structures of squids. These results confirm that using of slurry ice can extend the shelf-life and improve the safety and quality of squid, and thus extend the commercialization of fresh squid.

\section{ACKNOWLEDGMENTS}

This work was supported by a project granted by Chinese National Science and Technology (Project 2015BDA17B01), Chinese International Technology Cooperation Projects (Project 2012DFA30600), and the program of Zhejiang Aquatic Products Processing Technology Research Joint Laboratory (Zhejiang Ocean University, China).

\section{Author contributions}

Pengxian Yuan, was responsible for performing the experiments, the data collection, and revisions materials and methods section. Shanggui Deng, designed the experiment, assembled input data, and supervised the whole study. Shaimaa Hatab, contributed with the study design, interpreted the results, and drafted the manuscript. Ning Yuan, contributed to the Data analysis and interpretation, and Drafting the article. Jiancong Huo contributed to the experimental design, chemical composition analysis.

\section{REFERENCES}

Aubourg, S. P., V. Losada, M. Prado, J. M. Miranda and J. BarrosVelázquez. 2007. Improvement of the commercial quality of chilled Norway lobster (Nephrops norvegicus) stored in slurry ice: Effects of a preliminary treatment with an antimelanosic agent on enzymatic browning. Food Chem. 103: 741-748.

Aubourg, S. P., C. G. Sotelo and J. M. Gallardo. 1997. Quality assessment of sardines during storage by measurement of fluorescent compounds. J. Food Sci. 62: 295-298.

Benjakul, S. and F. Bauer. 2000. Physicochemical and enzymatic changes of cod muscle proteins subjected to different freezethaw cycles. J. Sci. Food Agric. 80: 1143-1150.

Benjakul, S., V. Wonnop, A. Tanong, T. Munehiko and M. Nikoo. 2011. ATPase activities and autolysis of kuruma prawn (Penaeus japonicus) muscle proteins. Int. Aquat. Res. 3: 53-61.

Cakli, S., B. Kilinc, T. Dincer and S. Tolasa. 2006. Effects of using slurry ice during transportation on the microbiological, chemical, and sensory assessments of aquacultured sea bass (Dicentrarchus labrax) stored at 4 degrees. CRC Crit. Rev. Food Sci. 46: 453-458.

Campos, C. A., V. Losada, Ó. Rodríguez, S. P. Aubourg and J. BarrosVelázquez. 2006. Evaluation of an ozone-slurry ice combined refrigeration system for the storage of farmed turbot (Psetta maxima). Food Chem. 97: 223-230.

Careche, M., M. L. Del Mazo, P. Torrejón and M. Tejada. 1998. Importance of frozen storage temperature in the type of aggregation of myofibrillar proteins in cod (Gadus morhua) fillets. J. Agric. Food Chem. 46: 1539-1546.

Careche, M., A. M. Herrero, A. Rodriguez-Casado, M. L. Del Mazo and P. Carmona. 1999. Structural changes of hake (Merluccius merluccius L.) Fillets: Effects of freezing and frozen storage. J. Agric. Food Chem. 47: 952-959.

Castrillón, A. M., E. Alvarez-Pontes, M. T. G. Arias and P. Navarro. 1996. Influence of frozen storage and defrosting on the chemical and nutritional quality of sardine (Clupea pilchardus). J. Sci. Food Agric. 70: 29-34.

Chantira, W., C. Manat and K. Sappasith. 2013. Physicochemical instability of muscles from two species of scad during iced storage. Chiang Mai J. Sci. 40: 681-688.

Gao, H. 2010. Analysis on quality of fresh cod (Gadus morhua) fillets pre-cooled with slurry ice and further superchilled storage. J. Refrig. 311: 48-52.

Gornall, A. G., C. J. Bardawill and M. M. David. 1949. Determination of serum proteins by means of the biuret reaction. J. Biol. Chem. 177: 751-766.

Gou, J., H. Y. Lee and J. Ahn. 2010. Effect of high pressure processing on the quality of squid (Todarodes pacificus) during refrigerated storage. Food Chem. 119: 471-476.

Hossain, M. I., M. Kamal, M. N. Sakib, F. H. Shikha, M. Neazuddin and M. N. Islam. 2005. Influence of ice storage on the gel forming ability, myofibrillar protein solubility and Ca2+-ATPase activity of queen fish (Chorinemus lysan). J. Biol. Sci. 5: 519-524.

Huidobro, A., M. E. López-Caballero and R. Mendes. 2002. Onboard processing of deepwater pink shrimp (Parapenaeus longirostris) with liquid ice: Effect on quality. Eur. Food Res. Technol. 214: 469-475.

Jeyasekaran, G., R. Jeya Shakila, D. Sukumar, P. Ganesan and R. Anandaraj. 2010. Quality changes in squid (Loligo duvaucelli) tubes chilled with dry ice and water ice. J. Food Sci. Technol. 47: 401-407.

Kauffeld, M., M. J. Wang, V. Goldstein and K. E. Kasza. 2010. Ice slurry applications. Int. J. Refrig. 33: 1491-1505.

Kjaersgard, I. V., M. R. Norrelykke and F. Jessen. 2006. Changes in cod muscle proteins during frozen storage revealed by proteome analysis and multivariate data analysis. Proteomics. 6: $1606-1618$ 
Ladrat, C., V. Verrez-Bagnis, J. Noël and J. Fleurence. 2003. In vitro proteolysis of myofibrillar and sarcoplasmic proteins of white muscle of sea bass (Dicentrarchus labrax L.): Effects of cathepsins B, D and L. Food Chem. 81: 517-525.

Leelapongwattana, K., S. Benjakul, W. Visessanguan and N. K. Howell. 2008. Effect of some additives on the inhibition of lizardfish trimethylamine-N-oxide demethylase and frozen storage stability of minced flesh. Int. J. Food Sci. Technol. 43: 448-455.

Lei, Y., Q. Xie and L. Y. 2007. The study on the treatment of high salinity wastewater. J.E.S.AM. 32: 94-98.

Losada, V., C. Piñeiro, J. Barros-Velázquez and S. Aubourg. 2004. Effect of slurry ice on chemical changes related to quality loss during European hake (Merluccius merluccius) chilled storage. Eur. Food Res. Technol. 219: 27-31.

Losada, V., C. Piñeiro, J. Barros-Velázquez and S. P. Aubourg. 2005. Inhibition of chemical changes related to freshness loss during storage of horse mackerel (Trachurus trachurus) in slurry ice. Food Chem. 93: 619-625.

Lu, F., S. L. Liu, R. Liu, Q. M. Ru and Y. T. Ding. 2012. Combined effect of ozonized water pretreatment and ozonized flake ice on maintaining quality of Japanese sea bass (Lateolabrax japonicus). J. Aquat. Food Prod. Technol. 21: 168-180.

Múgica, B., J. Barros-Velázquez, J. M. Miranda and S. P. Aubourg. 2008. Evaluation of a slurry ice system for the commercialization of ray (Raja clavata): Effects on spoilage mechanisms directly affecting quality loss and shelf-life. LWT Food Sci. Technol. 41: 974-981.

Okitani, A., U. Matsukura, H. Kato and M. Fujimaki. 1980. Purification and some properties of a myofibrillar protein-degrading protease, cathepsin L, from rabbit skeletal muscle. J. Biochem. 87: 1133-1143.

Ooizumi, T. and Y. L. Xiong. 2004. Biochemical susceptibility of myosin in chicken myofibrils subjected to hydroxyl radical oxidizing systems. J. Agric. Food Chem. 52: 4303-4307.

Piñeiro, C., J. Barros-Velázquez and S. P. Aubourg. 2004. Effects of newer slurry ice systems on the quality of aquatic food products: A comparative review versus flake-ice chilling methods. Trends Food Sci. Technol. 15: 575-582.

Ramirez-Suarez, J. C., L. R. Ibarra-León, R. Pacheco-Aguilar, M. E. Lugo-Sánchez, G. García-Sánchez and G. Carvallo-Ruiz. 2008. Physicochemical and functional changes in jumbo squid (Dosidicus gigas) mantle muscle during ice storage. Food Chem. 111: 586-591.
Reza, M. S., M. A. J. Bapary, C. T. Ahasan, M. N. Islam and M. Kamal. 2009. Shelf life of several marine fish species of Bangladesh during ice storage. Int. J. Food Sci. Technol. 44: 1485-1494.

Riebroy, S., S. Benjakul, W. Visessanguan and M. Tanaka. 2007. Effect of iced storage of bigeye snapper (Priacanthus tayenus) on the chemical composition, properties and acceptability of som-fug, a fermented Thai fish mince. Food Chem. 102: 270-280.

Rodríguez, A., N. Carriles, J. M. Cruz and S. P. Aubourg. 2008. Changes in the flesh of cooked farmed salmon (Oncorhynchus kisutch) with previous storage in slurry ice $\left(-1.5^{\circ} \mathrm{C}\right)$. LWT Food Sci. Technol. 41: 1726-1732.

Rodríguez, Ó., J. Barros-Velázquez, C. Piñeiro, J. M. Gallardo and S. P. Aubourg. 2006. Effects of storage in slurry ice on the microbial, chemical and sensory quality and on the shelf life of farmed turbot (Psetta maxima). Food Chem. 95: 270-278.

Rodríguez, Ó., V. Losada, S. P. Aubourg and J. Barros-Velázquez. 2005. Sensory, microbial and chemical effects of a slurry ice system on horse mackerel (Trachurus trachurus). J. Sci. Food Agric. 85: 235-242.

Rodríguez, Ó., V. Losada, S. P. Aubourg and J. Barros-Velázquez. 2004. Enhanced shelf-life of chilled European hake (Merluccius merluccius) stored in slurry ice as determined by sensory analysis and assessment of microbiological activity. Food Res. Int. 37: 749-757.

Schubring, R. 2005. Changes in texture, water holding capacity, colour and thermal stability of frozen cod (Gadus morhua) fillets: Effect of frozen storage temperature. Deut. Lebensmitt. Rundsch. 101: 484-493.

Sungsri-in, R., S. Benjakul and K. Kijroongrojana. 2011. Pink discoloration and quality changes of squid (Loligo formosana) during iced storage. LWT Food Sci. Technol. 44: 206-213.

Vleeming, B. J., F. J. C. van Bemmelen, M. R. Berends, R. D. B. Ouboter and A. N. Omelyanchouk. 1999. Measurements of the flux, embraced by the ring of a four-terminal squid, as a function of the external magnetic flux and the applied transport current. Phys. Condens. Matter. 262: 296-305.

Wang, H., A. M. Liceaga-Gesualdo and E. C. Y. Li-Chan. 2003. Biochemical and physicochemical characteristics of muscle and natural actomyosin isolated from young atlantic salmon (Salmo salar) fillets stored at 0 and $4^{\circ} \mathrm{C}$. J. Food Sci. 68: 784-789.

Zhang, B., S. G. Deng, M. Gao and J. Chen. 2015. Effect of slurry ice on the functional properties of proteins related to quality loss during skipjack tuna (Katsuwonus pelamis) chilled storage. J. Food Sci. 80: 695-702. 